\title{
Research Study of the Conditions of Wastes Lipolysis Lipid Fraction
}

\author{
Victoria Sklyar ${ }^{1 *}$, Galina Krussir ${ }^{1}$, Tetyana Lebedenko ${ }^{1}$, \\ Galina Khomich², Irina Kovalenko \\ 1 Odessa National Academy of Food Technologies, Kanatnaya Str, 112, Odessa, 65039, Ukraine \\ 2 Poltava University of Economics and Trade, Koval St., 3, Poltava, 36014, Ukraine \\ * Corresponding author's e-mail: vsklyar1993@gmail.com
}

\begin{abstract}
Biotechnological processing of secondary raw material resources of the oil and fat industry in useful products is the most expedient and effective in terms of both economic and environmental requirements. The obtained experimental results of the study indicate the prospect of lipolysis with the lipase Rhizopus japonicus fat fraction of waste generated during the hydrogenation of vegetable oils. The greatest activity in relation to olive oil is expressed by lipase Rhizopus oryzae. Lipase Rhizopus japonicus exhibits the highest activity relative to hydrogenated fat, which is explained by its substrate specificity. It was found that the content of free fatty acids in the hydrolyzate reached the saturation level after 72 hours of hydrolysis, and the concentration of triglycerides during this time of hydrolysis decreased to a minimum value. The results of research should be used to improve the processing technology of waste oil and fat industry in the food industry.
\end{abstract}

Keywords: secondary raw materials, soapstock, oilseed fat industry, ecological biotechnology, lipolysis

\section{INTRODUCTION}

Food and processing industry, like many other branches of the national economy, are a source of negative environmental impacts, that is, the source of its pollution. Low-waste and non-waste technologies, which are now called eco-friendly, on the one hand, allow all valuable components maximally and comprehensively extract raw materials, turning them into useful products, and on the other hand, to exclude or reduce the damage to the environment by the formation and penetration into the environment of waste production. Now, the transfer of production on the closed cycles is considered as one of the fundamental directions in solving issues of rational use of natural resources and environmental protection. The requirements of the modern market dictate the necessity of creation and implementation of the technologies with low energy, resource and capital intensity into production, allowing to produce high-quality and competitive products.
The technological processes of the production used today are mostly high-wasted. Therefore, the volume of potentially recyclable wasteamounts to about 3.0 billion tons annually, in the whole in Ukraine. A significant part of them is formed during the processing of raw materials in food and processing industry. The main part of recyclable materials (about 70\%) is supplied in agriculture in a native form, while more than $10 \%$ is not used. Along with the economic aspect, i.e. the expansion of the potential resource of recyclable materials, which is especially important at the moment due to its general deficit, the use of recyclable materials and wastes also has an environmental aspect, because in a result of non-use of wastes and uncontrolled ejection into water, air and the soil, increases the anthropogenic pressure for the environment, which leads to the lack of balance of the ecological systems.

Lipid and the products of the fat splitting, which contain soapstocks are valuable raw materials for food and process, as well as other industries such as mechanical rubber, paint 
and coating, cosmetics industries etc. Biotechnological recycling of recyclable raw materials into useful products is the most expedient and effective in terms of both economic and environmental requirements. Biotechnological processes of processing are based on natural processes, which practically have no side-effects, are productive and safe for biota and environmental components. Therefore, the search of biotechnological ways of the fat splitting fraction of the oil and fat industry wastes is the current task.

\section{MATHERIALS AND METHODS}

In the oil and fat industry, in the processing of seeds of oilseeds and the production of vegetable oil, margarine products and mayonnaise, the following SRM, by-products and waste products are formed: sunflower peelings, presscakes, oilcakes, phosphate concentrates, soapstock fats, distillation cut of deodorization, spent filter powder and catalyst, soda solutions, tars, drain water. The secondary raw materials of the oilfat industry and waste can be classified by the sources of formation:

- at the stage of pressing and forepressing - extraction of oilseeds - the secondary raw materials are presscake and oil meal; sunflower peeling is waste;

- at the stage of hydration of the oil as SRM phosphoric acid concentrates are obtained;

- at the stage of neutralization or alkaline refinement, the secondary raw materials are soapstock fats and spent alkaline solutions;

- in the process of bleaching the oil as waste, the secondary raw materials receives fat contained. in the used discolouring clay;

- when deodorizing vegetable oils and fats, the secondary raw materials (by-product) are formed, there is a distillation cut of deodorization;

- in the case of hydrogenation of oils and fats (obtaining food hydrogenated fat for margarine and technical one for soap making), waste is a fat in spent catalyst;

- during filtration of oils, the spent powder is obtained.

Some wastes of soap, drying oils, mayonnaise, olein, stearin, glycerin also occur in the production.
The following directions of low-waste and non-waste technologies are most promising in the fat-and-oil industry:

- non-waste technology for the production of highly concentrated vegetable proteins based on soybeans for use in products of mass, children, dietic, medical and preventive nutrition;

- implementation of a complex of measures for reducing water consumption, cleaning of gasoline-based no fat drain with the use of progressive methods, in particular, membranous ones;

- oil refinement technology according to the scheme: steam hydration - neutralization in the soap-alkaline environment - filtration for the purpose of more complete removal and rational use of phosphatides and the receipt of commodity products of them;

- development and implementation of new processes and equipment (boiler units), which ensure the production of a technological steam by burning sunflower peelings;

- biotechnological processing of secondary raw material resources of the oil and fat industry into useful products.

The main directions of using secondary raw materials in the oil and fat industry of the food and processing industry are given in Table 1 .

Soapstock is one of the most significant of volumes by waste forming witch releasing of alkaline neutralization of fats and oils. According to the current normative documentation, soapstocks are divided into the soapstocks from light oils and the soapstocks from hydrogenated fats and animal fats according to physical and chemical characteristics. The mass fraction of total fat in soapstock according to the standard is at least $25 \%$, and fatty acids comprise at least $15 \%$.

Fatty acids of soapstock are used mainly in soap production, as well as in the production of oleic and stearic acids, drying oils, and others. The objects of the study were 7 lipolytic enzyme preparations, the characteristics of which are given in Table 2, as well as the soapstock from the hydrogenated fat (PJSC "Odessa Oil and Fat Complex").

The lipolytic activity was determined with the titrimetric method by Ota and Yamada, which is based on the calculation of the amount of fatty acids formed during hydrolysis of the substrate. As a substrate, $40 \%$ emulsion of olive oil was used, which was stabilized with polyvinyl alcohol. Such amount of enzyme that liberates $1 \mathrm{mi}-$ cromole of oleic acid from $40 \%$ suspension of olive oil at $37^{\circ} \mathrm{C}$ for 1 hour under the conditions 
Table 1. Use of secondary raw materials in the oil and fat industry

\begin{tabular}{|c|c|c|c|}
\hline \multirow{2}{*}{$\begin{array}{l}\text { Seconadary raw } \\
\text { materials }\end{array}$} & \multicolumn{3}{|c|}{ Directions of use } \\
\hline & Food & Feed & Technical and so on \\
\hline Sunflower peelings & - & Feeding yeast & Fuel, furfural \\
\hline $\begin{array}{l}\text { Oilseed meal and } \\
\text { presscake }\end{array}$ & - & $\begin{array}{l}\text { Fodder in natural kind, } \\
\text { combined fodder and } \\
\text { in natural form and in } \\
\text { granules enriched with } \\
\text { lipids }\end{array}$ & - \\
\hline Phosphatides & $\begin{array}{l}\text { Addition for margarine, bakery and } \\
\text { confectionery }\end{array}$ & $\begin{array}{l}\text { Addition for dairy } \\
\text { products and to } \\
\text { combined fodder }\end{array}$ & - \\
\hline Soapstocks & - & - & $\begin{array}{c}\text { Household soap, rubber goods, } \\
\text { waterproof impregnation of } \\
\text { technical textiles, paint and coating } \\
\text { industry }\end{array}$ \\
\hline Bleaching clays & - & $\begin{array}{l}\text { Addition for combined } \\
\text { fodder }\end{array}$ & ( \\
\hline $\begin{array}{l}\text { Distillate cut of } \\
\text { deodorization }\end{array}$ & - & $\begin{array}{c}\text { Addition for fur animals' } \\
\text { feed }\end{array}$ & - \\
\hline Tars & - & - & $\begin{array}{l}\text { Surface-active substances for } \\
\text { flotation of ores, addition mater } \\
\text { road construction }\end{array}$ \\
\hline $\begin{array}{l}\text { Calcium salts of fatty } \\
\text { acids }\end{array}$ & - & - & $\begin{array}{l}\text { Polygraphics, construction of } \\
\text { roads, lubricants }\end{array}$ \\
\hline
\end{tabular}

Table 2. Characteristics of lipolytic enzyme preparations

\begin{tabular}{|c|c|c|c|c|c|}
\hline \multirow{2}{*}{ Lipase } & \multirow{2}{*}{ Producer } & \multicolumn{2}{|c|}{ Optimal conditions } & \multirow{2}{*}{ Enzyme activity } & \multirow{2}{*}{ Origin } \\
\hline & & $\mathrm{pH}$ & $\mathrm{t}, \mathrm{C}$ & & \\
\hline Lipase MM & Mucor miehei & $6,5-7,5$ & 40 & $4,000 \mathrm{U} / \mathrm{mg}$ & Sigma-aldrich \\
\hline Ліпаза RJ & $\begin{array}{l}\text { Rhizopus } \\
\text { japonicus }\end{array}$ & $\begin{array}{c}4.0-8.0 \\
(7)\end{array}$ & $\begin{array}{c}25-45 \\
(37)\end{array}$ & $\begin{array}{c}50000 \mathrm{U} / \mathrm{g} \text { to } \\
5058593,8 \mathrm{U} / \mathrm{g}\end{array}$ & Ladyzhin ENZIM \\
\hline Lipase RO & $\begin{array}{l}\text { Rhizopus } \\
\text { oryzae }\end{array}$ & $\begin{array}{c}2.5-8.0 \\
(5.5)\end{array}$ & $\begin{array}{c}15-65 \\
(37)\end{array}$ & $1,000 \mathrm{U} / \mathrm{g}$ to $150,000 \mathrm{U} / \mathrm{g}$ & BIO-CAT \\
\hline Lipase AN & $\begin{array}{l}\text { Aspergillus } \\
\text { niger }\end{array}$ & $7.0-11.0$ & $20-60$ & $1,000 \mathrm{U} / \mathrm{g}$ to $15,000 \mathrm{U} / \mathrm{g}$ & BIO-CAT \\
\hline Lipase G AO & $\begin{array}{l}\text { Aspergillus } \\
\text { oryzae }\end{array}$ & $\begin{array}{c}3.0-9.5 \\
(7)\end{array}$ & $\begin{array}{c}20-65 \\
(45)\end{array}$ & $100 \mathrm{KLU} / \mathrm{g}$ & BIO-CAT \\
\hline Yeast Lipase & $\begin{array}{l}\text { Candida } \\
\text { cylindracea } \\
\text { (rugosa) }\end{array}$ & $5.0-10.0$ & $40-50$ & $1,000 \mathrm{U} / \mathrm{g}$ to $200,000 \mathrm{U} / \mathrm{g}$ & BIO-CAT \\
\hline Lipase A & E.Coli & $5.0-10.0$ & $40-50$ & $3000 \mathrm{U} / \mathrm{g}$ & https://www.mybiosource.com/ \\
\hline
\end{tabular}

described below was taken up as an activity unit. In a test tube of the sample $8-15 \mathrm{mg}, 1 \mathrm{~cm}^{3}$ of water was put, $0.1 \mathrm{~cm}^{3}$ of a $0.1 \%$ solution of lipase, $0.8 \mathrm{~cm}^{3}$ of phosphate buffer (the $\mathrm{pH}$ environment corresponded to the $\mathrm{pH}$-optimum of lipase) and thermostated for 5 minutes at $37^{\circ} \mathrm{C}$. Then, $1.0 \mathrm{~cm}^{3}$ of $40 \%$ suspension of olive oil was added with polyvinyl alcohol, thermostated under the same conditions. Exactly after 1 hour of incubation, the reaction was interrupted with the addition of $5 \mathrm{~cm}^{3}$ of $96 \%$ ethanol. In the control sample, the emulsion of olive oil was added after the addition of ethanol. In the control and experimental samples, three drops of phenolphthalein solution were added and titriated with $0.05 \mathrm{~N}$ sodium hydroxide solution to a light pink color. The level of lipase activity was estimated in terms of the difference in the amount of alkali that went into the titration of experimental and control samples with hydrolysis of $40 \%$ of the emulsion of olive oil. The activity of lipase was calculated according to the formula:

$$
A=\frac{\left(A-A_{1}\right)}{B} \cdot 100
$$

where: $\mathrm{A}$-amount of $0.05 \mathrm{~N} \mathrm{NaOH}$ that was used for the titration of the prototype, $\mathrm{cm}^{3}$;

A1 - amount of $0.05 \mathrm{NNaOH}$ that was used for the titration of the control sample, $\mathrm{cm}^{3}$; $\mathrm{B}$ - the amount of enzyme in the reaction mixture, mg;

100 - coefficient for conversion into a micromolar. 
In order to exclude the influence on lipase for mineral substances contained in soapstocks, $40 \%$ emulsion of hydrogenated fat was used as a substrate in lipase fermentolysis, under the same conditions of fermentolysis.

The lipid composition of the hydrolysates was determined with thin-layered chromatography on Sorbfill-PTSK-AF-A (100x100 mm) plates with a solvent system petroleum ether (40-70): diethyl ether: acetic acid $=80: 20: 1$. The development of the resulted chromatograms was carried out in a iodine saturated desiccator, further chromatograms were scanned for $600 \mathrm{dpi}$ and processed using the program "TLC-Manager 4.0.1".

\section{RESULTS}

The choice of the lipases for study was based on the fact that the active producers of lipases are bacteria of Pseudomonas, Bacillus, actinomyces Streptomyces, Thermoactinomyces, yeasts Candida (Yarrowia), micellar mushrooms (fungus, fungi) Rhizopus, Aspergillus, Geotrichum. From the results of the studies presented in Figure 1, it is evident that lipase Rhizopus oryzae shows the highest activity in relation to olive oil. The highest activity in relation to hydrogenated fat characterizes lipase Rhizopus japonicus, which was later used for fermentolysis waste oil and fat industry. As it is known, the activity of the enzyme depends on the substrate and its characteristics (fatty acid composition, etc.), that is, it is substrate-specific, which can explain the difference in the activity of the lipases studied in relation to different substrates.

The dynamics of hydrolysis of hydrogenated fat was investigated under the conditions of the reverse emulsion, with low water content in the reaction environment for the ratio of fat: water $=4: 1$. The process was conducted under stationary conditions for 120 hours. It was established (Table 3) that the content of free fatty acids in the hydrolyzate reached saturation (almost the maximum value) already after 72 hours of hydrolysis, and the concentration of triacylglycerols during this time of hydrolysis was reduced to a minimum value.

\section{CONCLUSIONS}

The obtained experimental results of the research study indicate the prospect of lipolysis by lipase Rhizopus japonicus of waste lipid fraction, generated during the hydrogenation of vegetable oils. The highest activity in relation to the olive oil is expressed by lipase Rhizopus oryzae, the lipase Rhizopus japonicus is characterized by the highest activity relative to hydrogenated fat, which is explained by its substrate specificity. It was found that the content of free fatty acids in the hydrolyzate reached saturation level after 72 hours of hydrolysis, and the concentration of triglycerides during this time of hydrolysis decreased to a minimum value. The results of research should be used to improve the processing technology of waste oil and fat industry in the food and process industry.

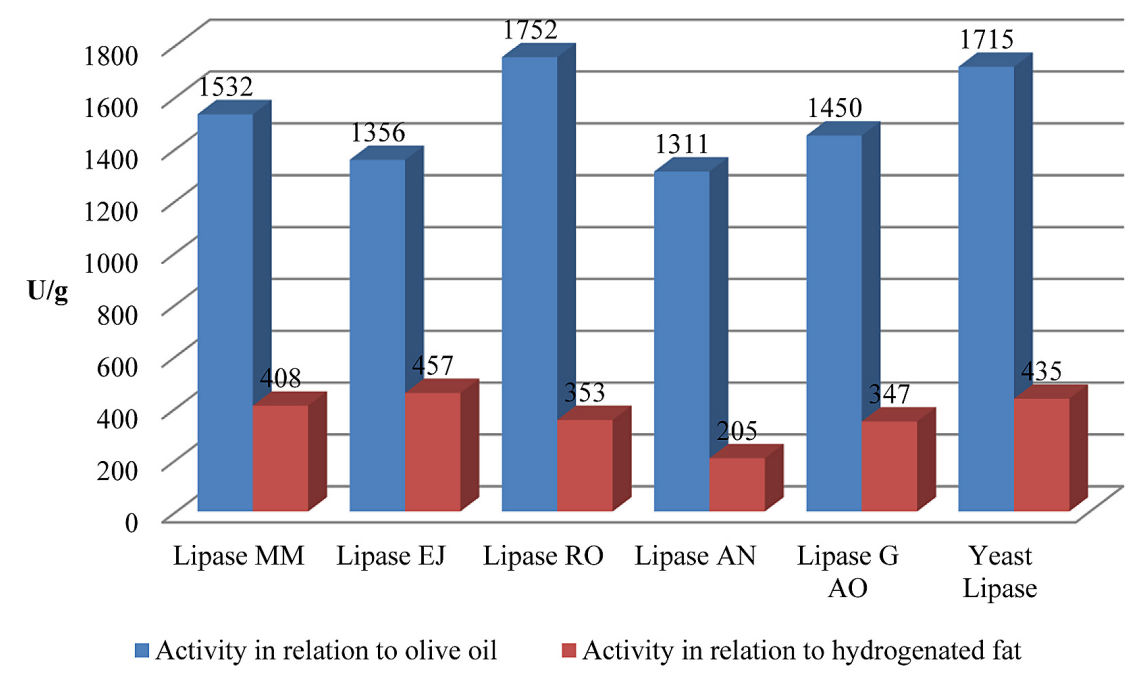

Fig. 1. Characterization of substrates' fermentolysis 
Table 3. Dynamics of change in lipid composition of hydrogeated fat during fermentolysis

\begin{tabular}{|c|c|c|c|c|}
\hline \multirow{2}{*}{ Time of hydrolysis. hour } & \multicolumn{4}{|c|}{ Consumption of lipids. \% } \\
\cline { 2 - 5 } & monoglyceride & diglyceride & triglyceride & fatty acids \\
\hline 0 & 0 & 9.5 & 88.1 & 25.7 \\
\hline 24 & 3.3 & 15.1 & 53.4 & 52.5 \\
\hline 48 & 4.2 & 17.5 & 20.3 & 60.1 \\
\hline 72 & 3.4 & 13.8 & 13.5 & 62.1 \\
\hline 96 & 3.2 & 11.9 & 11.2 & 64.5 \\
\hline
\end{tabular}

\section{REFERENCES}

1. Cherno N.K., Krussir G.V., Kovalenko O.V. 2009. Biocorrectors of etching processes Monograph. Astroprint, Odessa (in Ukrainian).

2. Kates M. 1975. The technique of lipidology. Isolation, analysis and identification of lipids, Mir, Moscow (in Russian).

3. Krussir G.V., Sevast'yanova O.V. 2007. Rapeseed - a source of high-grade lipase. Progressive technique and technologies of food production, restaurant econ- omy and trade, 1 (5), 193-197 (in Ukrainian).

4. Krussir G.V., Shevchenko R.I., Ruseva Ya.P., Kondratenko I.P., Kraynov I.P. 2014. Technologies of waste management of food production Astroprint, Odessa (in Ukrainian).

5. Polygalina G.V. 2003. Determination of enzyme activity. Directory. DeLi print, Moscow (in Russian).

6. Sagdeeva O.A., Krussir G.V., Tsykalo A.L., Shругко T.V., Leuenberger H. 2018. Composting of organic waste wiste with the use of mineral additives. Food Science and Technology, 12(1), 45-52. 